medRxiv preprint doi: https://doi.org/10.1101/2020.07.29.20164590; this version posted August 1, 2020. The copyright holder for this preprint (which was not certified by peer review) is the author/funder, who has granted medRxiv a license to display the preprint in perpetuity.

It is made available under a CC-BY-NC-ND 4.0 International license .

\title{
Household transmission of SARS-CoV-2: a systematic review and meta-analysis of secondary attack rate
}

Zachary J. Madewell*, Yang Yang, Ira M. Longini Jr, M. Elizabeth Halloran, Natalie E. Dean

$\underline{\text { Author affiliations: }}$

Department of Biostatistics, University of Florida, Gainesville, FL (ZJM, YY, IML, NED)

Fred Hutchinson Cancer Research Center, Seattle, WA (MEH)

Department of Biostatistics, University of Washington, Seattle, WA (MEH)

* Correspondence to: Zachary J. Madewell, Department of Biostatistics, University of Florida, PO Box

117450, Gainesville, FL 32611; zmadewell@ufl.edu 
medRxiv preprint doi: https://doi.org/10.1101/2020.07.29.20164590; this version posted August 1, 2020. The copyright holder for this preprint (which was not certified by peer review) is the author/funder, who has granted medRxiv a license to display the preprint in perpetuity.

It is made available under a CC-BY-NC-ND 4.0 International license .

\section{Summary}

Background: Severe acute respiratory syndrome coronavirus 2 (SARS-CoV-2) is spread by direct, indirect, or close contact with infected people via infected respiratory droplets or saliva. Crowded indoor environments with sustained close contact and conversations are a particularly high-risk setting.

Methods: We performed a meta-analysis through July 29, 2020 of SARS-CoV-2 household secondary attack rate (SAR), disaggregating by several covariates (contact type, symptom status, adult/child contacts, contact sex, relationship to index case, index case sex, number of contacts in household, coronavirus).

Findings: We identified 40 relevant published studies that report household secondary transmission. The estimated overall household SAR was $18 \cdot 8 \%$ (95\% confidence interval [CI]: $15 \cdot 4 \%-22 \cdot 2 \%$ ), which is higher than previously observed SARs for SARS-CoV and MERS-CoV. We observed that household SARs were significantly higher from symptomatic index cases than asymptomatic index cases, to adult contacts than children contacts, to spouses than other family contacts, and in households with one contact than households with three or more contacts.

Interpretation: To prevent the spread of SARS-CoV-2, people are being asked to stay at home worldwide. With suspected or confirmed infections referred to isolate at home, household transmission will continue to be a significant source of transmission. 
medRxiv preprint doi: https://doi.org/10.1101/2020.07.29.20164590; this version posted August 1, 2020. The copyright holder for this preprint (which was not certified by peer review) is the author/funder, who has granted medRxiv a license to display the preprint in perpetuity.

It is made available under a CC-BY-NC-ND 4.0 International license .

\section{Introduction}

The coronavirus disease 2019 (COVID-19) pandemic is caused by severe acute respiratory syndrome coronavirus 2 (SARS-CoV-2). First identified in Wuhan, China, in January 2020, SARS-CoV2 has now been reported worldwide in 214 countries and territories. ${ }^{1}$ Although COVID-19 often presents clinically as a mild disease, it may cause severe illness or even death, particularly among older individuals and those with concurrent chronic diseases. ${ }^{2,3}$ SARS-CoV-2 is spread via direct, indirect, or close contact with infected people via infected respiratory droplets or saliva. ${ }^{4}$ Airborne and fomite transmission are other potential routes. ${ }^{5}$ Crowded indoor environments with sustained close contact and conversations are a particularly high-risk setting. ${ }^{6}$

Stay-at-home orders implemented in response to the pandemic reduced human mobility by 35$63 \%$ in the USA, ${ }^{7} 63 \%$ in the UK, ${ }^{8}$ and $54 \%$ in Wuhan, ${ }^{9}$ relative to normal conditions. This concomitantly increased time spent at home and likely increased household transmission of SARS-CoV-2. For example, following campaigns promoting social distancing and bans on social gatherings, Iceland observed a shift in exposure from international travel and social exposure to exposure in the household environment. ${ }^{10}$ The WHO-China Joint Mission reported that most locally generated cases were clustered in households. ${ }^{11}$ While current CDC recommendations are to maintain six feet distance from when a household member is sick, this may be difficult to achieve in practice nor be fully effective. ${ }^{12}$

Studies of household contacts are uniquely advantageous for understanding transmission dynamics. Besides characterizing transmissibility in a household setting, household secondary attack rate (SAR) provides a useful estimate of both the susceptibility of contacts and infectiousness of index cases. Studies can collect detailed data on the type, timing and duration of contacts. Researchers can examine features of the household, such as density or sanitization methods. ${ }^{13}$ This information may be used to inform control measures.

We conducted a review of the rapidly growing body of literature describing household transmission of SARS-CoV-2. We describe the types of study designs available and then present a metaanalytic summary of transmission within households for SARS-CoV-2, disaggregated by several 
medRxiv preprint doi: https://doi.org/10.1101/2020.07.29.20164590; this version posted August 1, 2020. The copyright holder for this preprint (which was not certified by peer review) is the author/funder, who has granted medRxiv a license to display the preprint in perpetuity.

It is made available under a CC-BY-NC-ND 4.0 International license .

exposures. We discuss available evidence for asymptomatic and presymptomatic exposure, as well as correlates of susceptibility of household contacts and infectivity of index cases. We also explore how many households with index cases had any secondary transmission, and compare household transmission with other coronaviruses.

\section{Review of transmissibility of SARS-CoV-2 in households and families}

We estimated transmissibility of SARS-CoV-2 within the household or family by the crude secondary attack rate (SAR), or the probability that an exposed susceptible person develops disease over the duration of infectiousness in a case patient. The denominator of the SAR is the number of exposed contacts, and the numerator is the number who become infected with SARS-CoV-2 or develop COVID19.

To estimate household SAR, we searched PubMed using the terms "SARS-CoV-2" or "COVID19" plus: "secondary attack rate," "household," "close contacts," "contact transmission," "contact attack rate," "family transmission," or "family attack rate." We extracted all articles with original data for estimating household SAR of SARS-CoV-2. The publication must report a numerator and denominator among household contacts, or at least two of numerator, denominator, and SAR. Where numerators (numbers of infected contacts) or denominators (numbers of contacts) were not reported but the number of index cases and SAR were available, the denominator was calculated acknowledging limits of significant digits. The last search was conducted on July 29, 2020.

We identified 40 relevant published studies that report household secondary transmission (Figure 1; S1 Table). Most studies were in China, ${ }^{14-32}$ but others were in South Korea, ${ }^{33-37}$ USA, ${ }^{38-41}$ Spain, ${ }^{42,43}$ Australia, ${ }^{44}$ Brazil,${ }^{45}$ Brunei,${ }^{46}$ Germany,${ }^{47}$ India,${ }^{48}$ Israel,${ }^{49}$ Italy, ${ }^{50}$ Singapore,${ }^{51}$ Taiwan, ${ }^{52}$ and UK.${ }^{53}$ 
medRxiv preprint doi: https://doi.org/10.1101/2020.07.29.20164590; this version posted August 1, 2020. The copyright holder for this preprint (which was not certified by peer review) is the author/funder, who has granted medRxiv a license to display the preprint in perpetuity.

It is made available under a CC-BY-NC-ND 4.0 International license .

Figure 1. Flowchart for review of household secondary attack rate
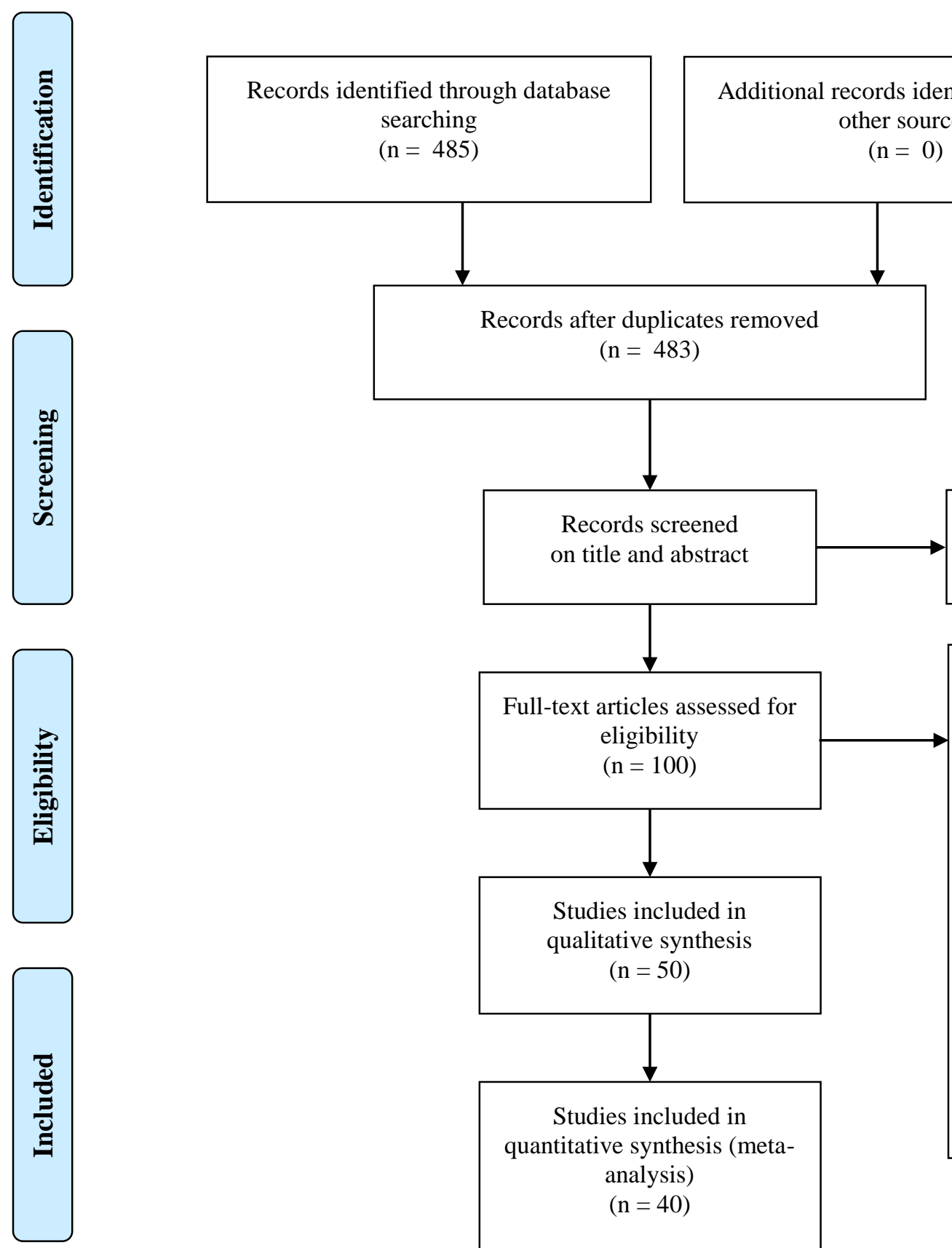

\begin{tabular}{|c|c|}
\hline $\begin{array}{l}\text { Records screened } \\
\text { on title and abstract }\end{array}$ & $\begin{array}{l}\text { Records excluded } \\
\quad(\mathrm{n}=383)\end{array}$ \\
\hline$\downarrow$ & \multirow{7}{*}{$\begin{array}{l}\text { Full-text articles excluded, with } \\
\qquad \begin{array}{l}\text { reasons } \\
(\mathrm{n}=50)\end{array} \\
\text { - Case reports or cluster } \\
\text { investigations that focused on } \\
\text { individual households or families } \\
(\mathrm{n}=22) \\
\text { - No data on household/family } \\
\text { contacts }(\mathrm{n}=15) \\
\text { - No data on uninfected contacts } \\
(\mathrm{n}=7) \\
\text { - No original data }(\mathrm{n}=3) \\
\text { - Reported seroprevalence } \\
\text { without transmission }(\mathrm{n}=3)\end{array}$} \\
\hline \multirow{2}{*}{$\begin{array}{l}\text { Full-text articles assessed for } \\
\text { eligibility } \\
(\mathrm{n}=100)\end{array}$} & \\
\hline & \\
\hline$\downarrow$ & \\
\hline $\begin{array}{l}\text { Studies included in } \\
\text { qualitative synthesis } \\
\qquad(\mathrm{n}=50)\end{array}$ & \\
\hline$\downarrow$ & \\
\hline $\begin{array}{l}\text { Studies included in } \\
\text { quantitative synthesis (meta- }\end{array}$ & \\
\hline
\end{tabular}

analysis)

$(\mathrm{n}=40)$ 
Much of our understanding of household transmission is derived from contact tracing investigations. After a household member is confirmed to be infected with SARS-CoV-2, household or family contacts are identified, followed for a short duration of time (e.g., two weeks), and tested if eligible for testing according to national testing guidelines to ascertain secondary infections. Index cases were identified by passive surveillance, ${ }^{21,28,29,31,38-40,43,44,49-51}$ active surveillance of key populations (e.g., travelers from areas with active SARS-CoV-2 transmission, and individuals detected by neighborhood fever screenings), ${ }^{25,27,34}$ both active and passive surveillance, ${ }^{14,15,17-20,22,24,26,30,32,33,35,36,41,46,48,52,53}$ or regional seroprevalence surveys. ${ }^{42,45}$ We did not include case reports or cluster investigations that focused on individual households or families in an effort to reduce publication bias.

Some studies included index cases with SARS-CoV-2 infections (both symptomatic and asymptomatic), ${ }^{14,15,18-22,24-27,32-34,36,37,41,42,47,49,52}$ whereas others included symptomatic COVID-19 index cases only. ${ }^{16,28-31,38-40,43,44,50,51,53}$ Another targeted asymptomatic SARS-CoV-2 infected index cases, ${ }^{35}$ some of whom developed symptoms during a follow-up period. Most studies did not describe how co-primary index cases were handled or whether secondary infections could have been acquired from outside the household, both of which can inflate the crude SAR. Several stated they assumed all secondary cases were infected by the index case to whom they were traced, ${ }^{26,33,48}$ another excluded secondary cases if they developed symptoms before exposure to the primary case, ${ }^{52}$ and another randomly selected one index case as the infector. ${ }^{18}$ Ignoring tertiary transmission also inflates the SAR.

Many studies only included household contacts, ${ }^{14,26,28,29,31,35,37,38,40,41,43,49,50,53}$ but others included family members, ${ }^{15,20,21,23,27,30}$ or other close contacts, ${ }^{16-19,22,24,25,32-34,36,39,42,44,46-48,52}$ including individuals outside the household. Of the latter studies of close contacts, many reported SARs among household contacts, ${ }^{17,18,22,24,25,32-34,36,39,42,44,46-48,52}$ or all family members. ${ }^{16,19-21,23,27,30}$ We did not include studies of close contacts that did not report SARs for household or family members. We assumed that studies of household contacts included anyone living in the same household as the index case unless stated otherwise. For example, several studies reported household contacts as family members in 
households. ${ }^{25,28,32,45}$ Several studies further restricted household contacts to those who spent at least one night or 24 hours in the house after symptom onset of the index case. ${ }^{26,28,31}$

Most studies involved tracing contacts and monitoring them for $14,{ }^{14,16-18,22,24,28-34,37-39,44,47,48,50,52}$ or 21 days. ${ }^{19,26}$ Monitoring methods included phone calls, ${ }^{21,34,39,44}$ text messages, ${ }^{39,44}$ or direct observation by healthcare workers. ${ }^{17,33}$ Some studies tested all contacts immediately after the index case was diagnosed at the onset of the observation period and monitored them for symptoms. ${ }^{18,35,40,46,51}$ Several studies that reported testing all contacts irrespective of symptoms also reported extra testing of individuals who developed symptoms during quarantine. ${ }^{25,31,38,40,46}$ Others tested all contacts during or at the end of the observation period regardless of symptoms, ${ }^{24,28,37,48}$ whereas others only tested symptomatic contacts. ${ }^{29,39,44,50,52}$ Several studies tested contacts multiple times throughout the observation period irrespective of symptoms. ${ }^{14,17,19,22,25,26,30,31,33,38,47}$ Other studies tested all contacts, ${ }^{15,23,40-42,45}$ or interviewed index cases about symptoms of household members, ${ }^{43,53}$ immediately without additional monitoring. Many studies, particularly those in China, reported in-home quarantine of contacts during the observation period after index cases were confirmed. ${ }^{14,17-19,22,24,29-34,36,37,44,46,47,50-52}$

Case ascertainment was primarily done via RT-PCR on nasopharyngeal or oropharyngeal samples..$^{14,17,18,21-23,26-33,35-37,40,44,46-53}$ However, several studies also reported whole-genome sequencing, ${ }^{27,28,32,47}$ nucleic acid tests, ${ }^{19,25,27}$ and antibody tests. ${ }^{42,45}$ Two studies identified index cases via RT-PCR, but only collected symptom information about household contacts from telephone interviews with index cases. ${ }^{43,53}$

\section{Secondary attack rate}

Meta-analyses were done using a restricted maximum-likelihood estimator model to yield a point estimate and $95 \%$ confidence interval (CI) for SAR by exposure type. Each study was treated as a random effect and exposure (contact type, symptom status, adult/child contacts, contact sex, relationship to index case, index case sex, number of contacts in household, coronavirus) as a fixed effect. The Cochran Q-test 
medRxiv preprint doi: https://doi.org/10.1101/2020.07.29.20164590; this version posted August 1, 2020. The copyright holder for this preprint (which was not certified by peer review) is the author/funder, who has granted medRxiv a license to display the preprint in perpetuity.

It is made available under a CC-BY-NC-ND 4.0 International license .

is reported as a measure of heterogeneity. All tests of significance were at the $\alpha=0 \cdot 05$ level. All analyses were done in $\mathrm{R} 4 \cdot 0 \cdot 2$ using the package metafor. ${ }^{54,55}$

Figure 2 summarizes overall SARs for the 40 studies included. If a study reported SARs for both household and family contacts, we only included the household contact SAR to avoid counting the same individuals twice. The estimated mean SAR for household contacts is $19.0 \%$ (95\% CI: $14 \cdot 9 \%-23 \cdot 1 \%$ ) and family contacts is $18 \cdot 1 \%$ (95\% CI: $12 \cdot 9 \%-34 \cdot 8 \%)$, both with significant heterogeneity $(P<0 \cdot 001)$. SARs were not significantly different between household and family contacts, but they were nearly five times higher than SARs reported for close contacts $(4.3 \%$; $95 \%$ CI: $2.9 \%-5 \cdot 6 \%)(P<0 \cdot 001)$ (S1 Figure). Among studies that included other forms of contact outside the household, household contact was reported as a significant risk factor for infection. ${ }^{17,18,24,25,32,33,46,48}$ The household SAR for studies in China was not significantly different than SARs reported in studies from other countries (S2 Figure). There was no significant difference in SARs between studies that tested symptomatic contacts $(17 \cdot 8 \%$; $95 \%$ CI:

$2 \cdot 1 \%-33.6 \%)$ versus all contacts $(19 \cdot 7 \%$; $95 \%$ CI: $15 \cdot 4 \%-24.0 \%)$, both with significant heterogeneity $(P$ $<0.001)$ (S3 Figure). 
medRxiv preprint doi: https://doi.org/10.1101/2020.07.29.20164590; this version posted August 1, 2020. The copyright holder for this preprint (which was not certified by peer review) is the author/funder, who has granted medRxiv a license to display the preprint in perpetuity.

It is made available under a CC-BY-NC-ND 4.0 International license .

Figure 2. Secondary attack rates (SAR) for household contacts and family contacts (including individuals outside the index case household).

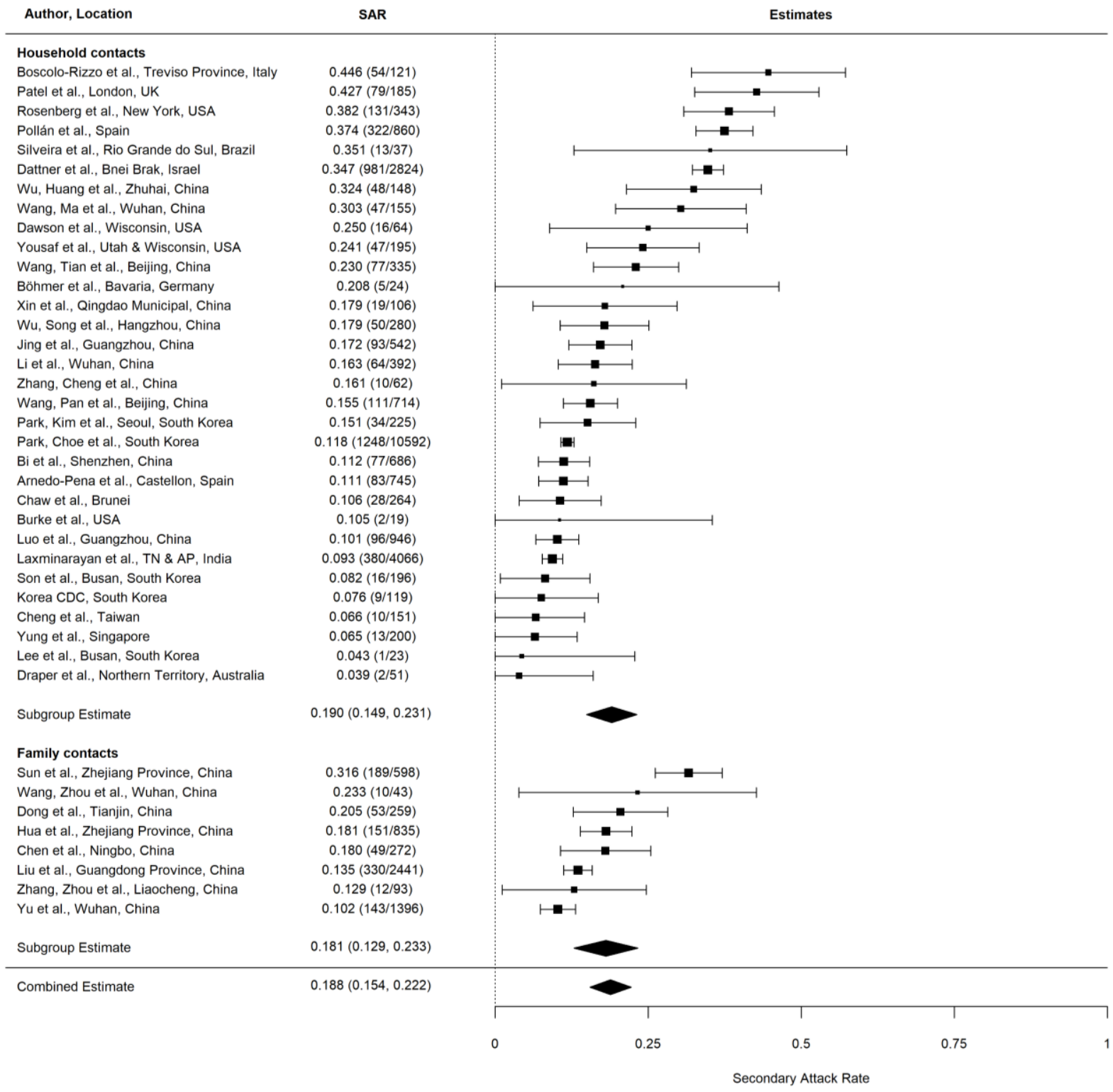

Presymptomatic, asymptomatic, and symptomatic transmission

To study the transmissibility of asymptomatic SARS-CoV-2 index cases, Figure 3 summarizes 17 studies reporting household SARs from symptomatic index cases and four from asymptomatic index cases. The estimated mean household SAR from symptomatic index cases (19.9\%; 95\% CI: $14 \cdot 0 \%-$ $25.7 \%)$ was significantly higher than from asymptomatic index cases $(0 \cdot 7 \%$; $95 \% \mathrm{CI}: 0 \%-3 \cdot 8 \%)(P<$ 0.001), though there were only a few studies of asymptomatic index cases. These findings are consistent 
medRxiv preprint doi: https://doi.org/10.1101/2020.07.29.20164590; this version posted August 1, 2020. The copyright holder for this preprint (which was not certified by peer review) is the author/funder, who has granted medRxiv a license to display the preprint in perpetuity.

It is made available under a CC-BY-NC-ND 4.0 International license .

with other household studies that reported asymptomatic index cases as having limited or no role in household transmission, ${ }^{17,25,52}$ although many studies acknowledged that asymptomatic index cases are likely under-represented. ${ }^{18,30,33,43,46,53}$

Figure 3. Secondary attack rates (SAR) from symptomatic and asymptomatic index cases to household and family $(*)$ contacts.

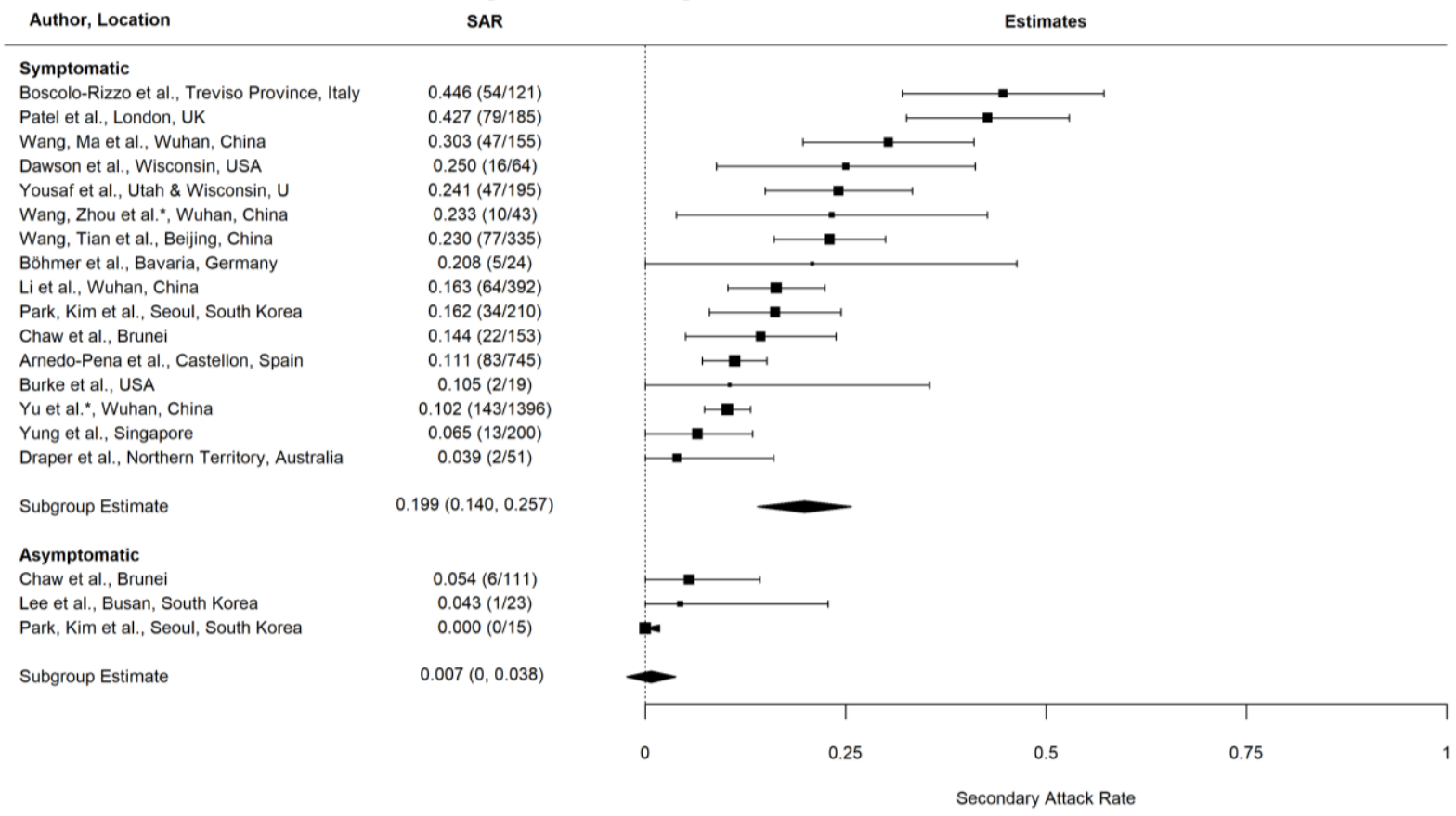

Several studies reported SARS-CoV-2 transmission prior to symptom onset of the index case. $^{22,25,30,52}$ One study reported higher risk of transmission after symptom onset relative to the incubation period. ${ }^{30}$ Others demonstrated that exposure after illness onset was not associated with secondary transmission, ${ }^{26,31,52}$ although close contacts and/or index cases were quarantined/isolated after symptom onset. Some studies reported that infection risk peaked during exposure 3-4 days before or within 5 days of symptom onset. ${ }^{30,52}$ One study reported higher SAR among close contacts of presymptomatic index cases than asymptomatic carriers. ${ }^{52}$ Thus, the evidence was mixed.

\section{Overdispersion}


There is evidence for strong clustering of SARS-CoV-2 infections within households, with some households having many secondary infections while many others have none. ${ }^{56-58}$ For example, one study reported that 26 of $103(25 \cdot 2 \%)$ households had all members test positive. ${ }^{41}$ In China, $78-85 \%$ of COVID19 clusters occurred in families. ${ }^{11}$ Most studies only reported the number of secondary infections per individual, but some also reported transmission by household. ${ }^{26,28,41,51}$ Figure 4 summarizes the proportion of households with any secondary transmission. Using a crude analysis based on the SAR and average number of contacts per household, we find that the proportion of households with any secondary transmission was lower than expected for all studies (see Appendix). Given the full data, fitting a betabinomial to household data would allow better detection of overdispersion.

Figure 4. The average number of contacts per household, secondary attack rate (SAR), and proportion of households reporting any secondary transmission from index cases. The blue triangles represent the expected proportion of households with any secondary transmission (see Appendix for further details).

\begin{tabular}{|c|c|c|c|c|c|c|c|c|}
\hline Author, Location & Avg. Contacts & SAR & Proportion & & & Estimates & & \\
\hline Wu, Huang et al., Zhuhai, China & 1.821 & $0.039(2 / 51)$ & $0.036(1 / 28)$ & & & 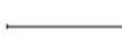 & 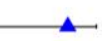 & \\
\hline Rosenberg et al., New York, USA & 1.493 & $0.065(13 / 200)$ & $0.052(7 / 134)$ & & & 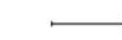 & $\longrightarrow \Delta$ & \\
\hline Wang, Tian et al., Beijing, China & 2.702 & $0.230(77 / 335)$ & $0.331(41 / 124)$ & & & $\longrightarrow \Delta$ & & \\
\hline Yung et al., Singapore & 3.330 & $0.382(131 / 343)$ & $0.612(63 / 103)$ & 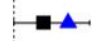 & & & & \\
\hline Draper et al., Northern Territory, Australia & 4.229 & $0.324(48 / 148)$ & $0.629(22 / 35)$ & -1 & & & & \\
\hline \multirow[t]{3}{*}{ Combined Estimate } & & & $0.325(0.074,0.575)$ & & & - & & \\
\hline & & & & I & T & T & T & \\
\hline & & & & 0 & 0.25 & 0.5 & 0.75 & 1 \\
\hline
\end{tabular}

\section{Risk factors for susceptibility}

A number of studies examined factors potentially associated with susceptibility of household contacts to infection (S2 Table). Age was the most examined covariate, with most studies reporting significantly lower secondary transmission of SARS-CoV-2 to children contacts than adult contacts. ${ }^{16,17,21,22,26,28,30,31,41,43,49}$ In three studies, individuals aged $>60$ years were most susceptible to SARS-CoV-2 infection. ${ }^{17,22,43}$ Contact age was not associated with susceptibility in six other studies, ${ }^{14,15,24,25,46,52}$ although these were typically less powered to detect a difference. Figure 5 
medRxiv preprint doi: https://doi.org/10.1101/2020.07.29.20164590; this version posted August 1, 2020. The copyright holder for this preprint (which was not certified by peer review) is the author/funder, who has granted medRxiv a license to display the preprint in perpetuity.

It is made available under a CC-BY-NC-ND 4.0 International license .

summarizes ten studies reporting separate SARs to children and adult contacts. The estimated mean

household SAR was significantly higher to adult contacts $(31 \cdot 0 \%$; $95 \%$ CI: $19 \cdot 4 \%-42 \cdot 7 \%)$ than to

children contacts $(15.7 \%$; 95\% CI: $9.9 \%-21.5 \%)(P<0.001)$, both with significant heterogeneity $(P<$

$0 \cdot 001)$.

Figure 5. Secondary attack rates (SAR) for adult ( $\geq 18$ years) and children $(<18$ years) household and family $(*)$ contacts.

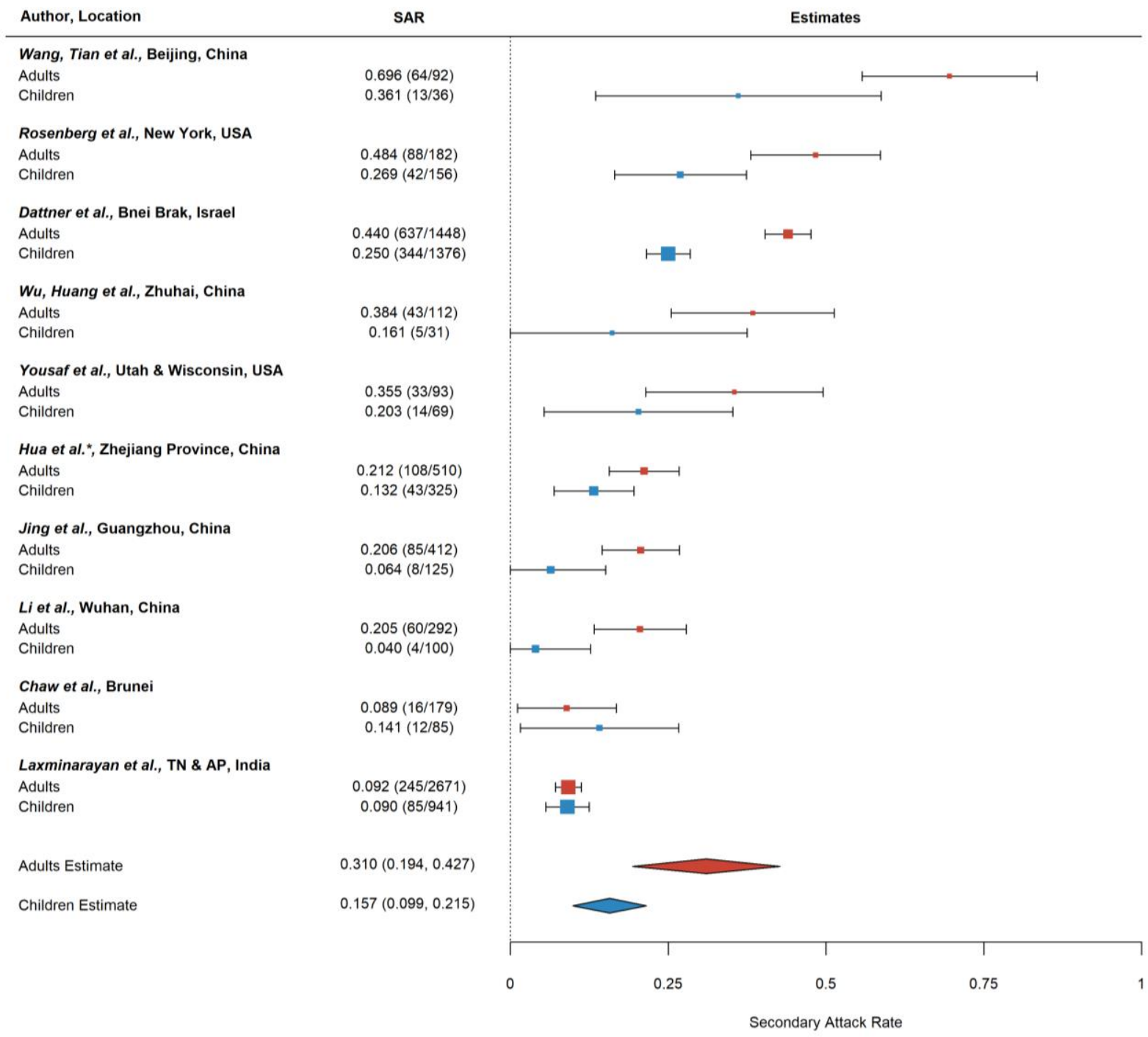

The second most examined factor was sex of the exposed contacts, which was not associated with transmission for most studies, ${ }^{15,17,18,22,24-26,31,46}$ except for two, ${ }^{16,30}$ which found higher risk in females than males. Figure 6 summarizes the results from nine studies reporting household SAR by contact sex. The 
medRxiv preprint doi: https://doi.org/10.1101/2020.07.29.20164590; this version posted August 1, 2020. The copyright holder for this preprint (which was not certified by peer review) is the author/funder, who has granted medRxiv a license to display the preprint in perpetuity.

It is made available under a CC-BY-NC-ND 4.0 International license .

estimated mean household SAR to females $(19 \cdot 4 \%$; $95 \%$ CI: $13 \cdot 0 \%-25 \cdot 8 \%)$ was not significantly different than to males $(16 \cdot 0 \%, 95 \%$ CI: $10 \cdot 3 \%-21 \cdot 8 \%)$, both with significant heterogeneity $(P<0 \cdot 001)$.

Figure 6. Secondary attack rates (SAR) for household and family $(*)$ contacts by contact sex.

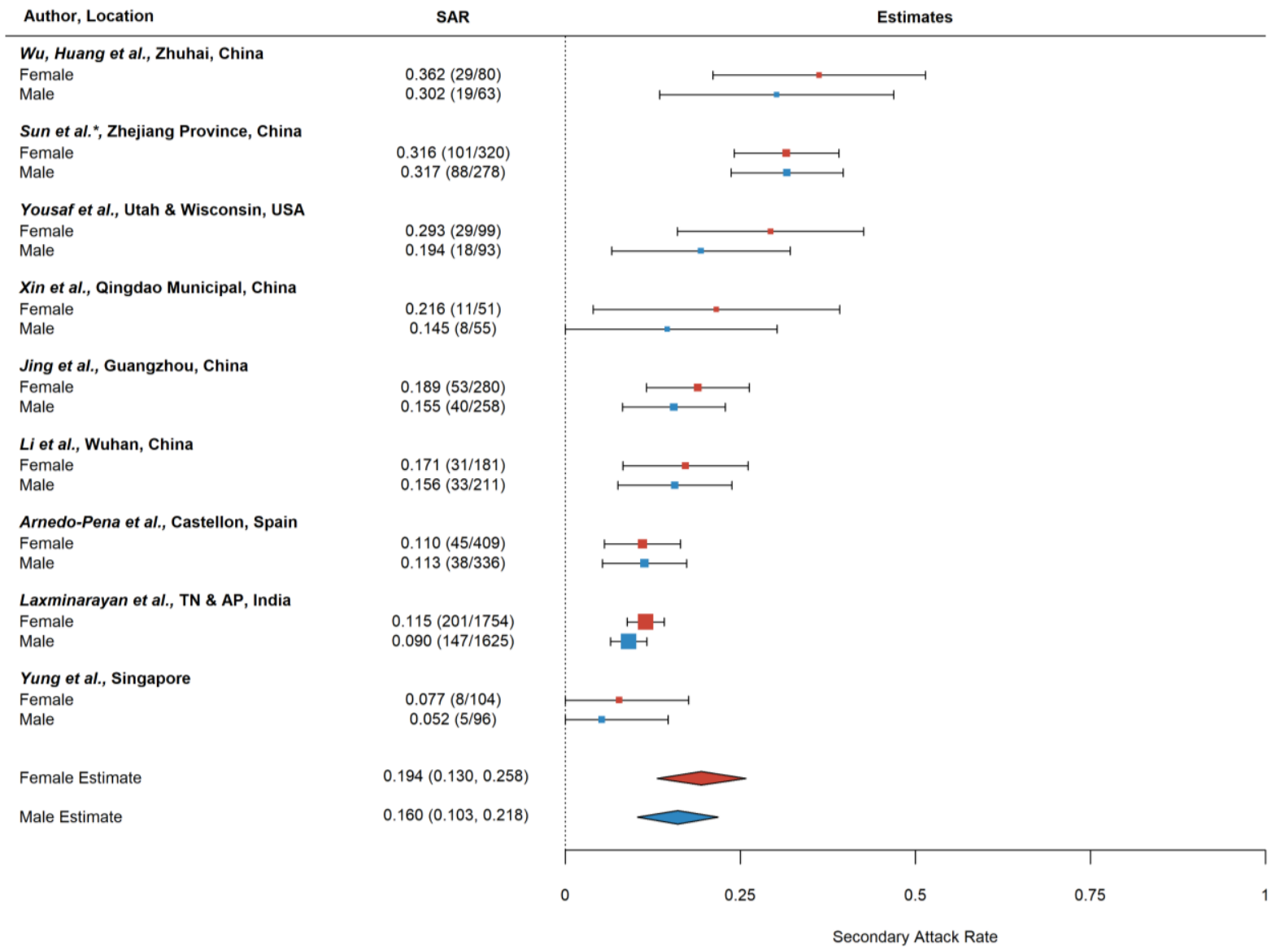

Spouse relationship to index case was associated with secondary infection in four, ${ }^{15,30,31,46}$ of six studies. ${ }^{14,26}$ The risk of infection was highest for spouses, followed by non-spouse family members, close relatives, and other relatives, which were all higher than other contacts. ${ }^{30}$ Figure 7 summarizes the results from five studies reporting household SAR by relationship. The estimated mean household SAR to spouses (43.4\%; 95\% CI: $27 \cdot 1 \%-59 \cdot 6 \%)$ was significantly higher than to other relationships (18.3\%, 95\% CI: $10 \cdot 4 \%-26 \cdot 2 \%)$. There was significant heterogeneity for spouse SARs between studies $(P=$ 
medRxiv preprint doi: https://doi.org/10.1101/2020.07.29.20164590; this version posted August 1, 2020. The copyright holder for this preprint (which was not certified by peer review) is the author/funder, who has granted medRxiv a license to display the preprint in perpetuity.

It is made available under a CC-BY-NC-ND 4.0 International license .

0.001), but not other relationships. A limitation is that studies do not report the direction of spousal transmission for male-female partnerships.

Figure 7. Secondary attack rates (SAR) for household and family $(*)$ contacts by relationship to index case (spouse, other).

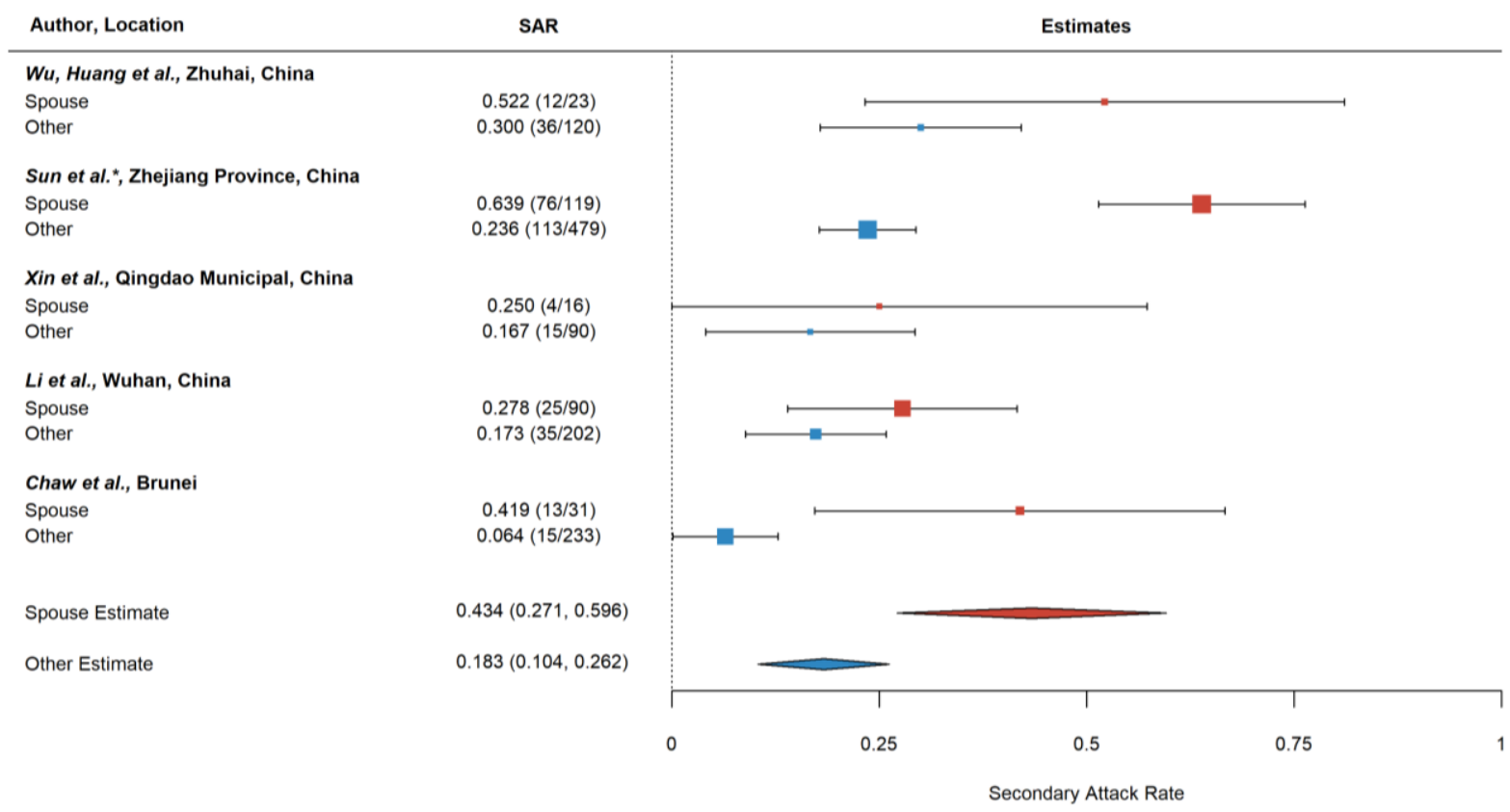

\section{Factors for infectiousness}

Several studies also examined factors associated with infectiousness of index cases. Older index case age was associated with increased secondary infections in two, ${ }^{14,43}$ of six studies. ${ }^{18,22,26,28}$ Female index case sex was associated with transmission in two, ${ }^{14,48}$ of six studies. ${ }^{26,28,31,43}$ Figure 8 summarizes the results from six studies reporting household SAR by index case sex. The estimated mean household SAR from females $(14 \cdot 6 \%$; $95 \%$ CI: $9 \cdot 3 \%-20 \cdot 0 \%)$ was not significantly different than from males (12.8\%, $95 \%$ CI: $8 \cdot 1 \%-17 \cdot 4 \%)$. 
Figure 8. Secondary attack rates (SAR) for household contacts by index case sex.

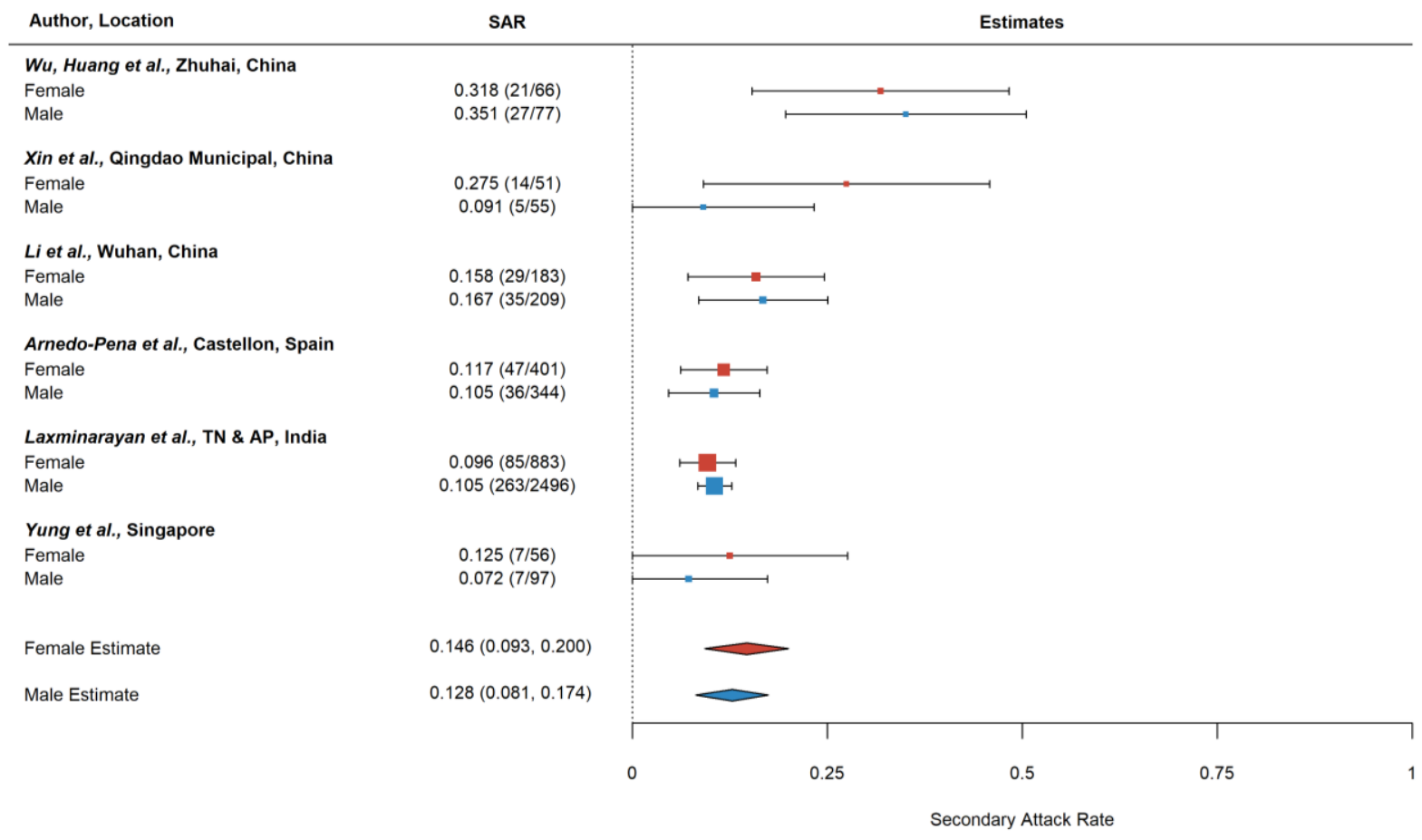

Critically severe index case symptoms and hospitalization were associated with higher infectiousness in four, ${ }^{14,17,30,43}$ of six studies where this was examined. ${ }^{25,28}$ Cough in the index case was associated with infectivity in two,${ }^{26,43}$ of seven studies. ${ }^{14,17,28,30,31}$ Diarrhea, ${ }^{28}$ pneumonia, ${ }^{43,52}$ acute respiratory distress syndrome,${ }^{52}$ myalgia,${ }^{30}$ chills,${ }^{30}$ dizziness,${ }^{30}$ lymphocyte count, ${ }^{14}$ neutrophil percentage, ${ }^{14}$ and expectoration, ${ }^{17}$ were also associated with secondary transmission in some studies. Symptoms not shown to be associated with infectivity were fever, ${ }^{14,17,26,28,30,31}$ fatigue, ${ }^{14,17,30}$ dyspnea, ${ }^{30}$ headache,${ }^{30}$ nasal congestion, ${ }^{30}$ pharyngalgia, ${ }^{30}$ arthralgia,${ }^{30}$ rhinorrhea,${ }^{30}$ nausea,${ }^{30}$ vomiting, ${ }^{30}$ chest tightness,${ }^{30}$ palpitation, ${ }^{30}$ poor appetite,${ }^{30}$ abdominal pain,${ }^{30}$ and white blood cell count. ${ }^{14}$

Household seroprevalence surveys that did not differentiate correlates of susceptibility vs. infectivity showed similar trends: sex was not associated with infection, ${ }^{42,56,59,60}$ and seroprevalence increased with age..$^{42,59}$

\section{Awareness and behavioral factors}


Contact frequency with the index case was associated with higher odds of infection, specifically $\geq 5$ contacts during 2 days before the index case was confirmed, ${ }^{25} \geq 4$ and $1-3$ contacts (within $1 \mathrm{~m}$ ), ${ }^{28}$ or frequent contact. ${ }^{14,16,18}$ Physical contact,${ }^{26}$ sharing a vehicle, ${ }^{17,18,24,26}$ sharing a living room, ${ }^{26}$ and sharing a meal, ${ }^{26,28}$ were also associated with infection, but eating with separate tableware was not. ${ }^{28}$ Smoking behavior in index cases or contacts was not associated with transmission. ${ }^{26}$

Several studies explored whether prevention measures were associated with reduced transmission. Contacts who wore face masks and index cases who wore masks all the time after illness onset had lower odds of infection and transmission, respectively. ${ }^{24,28}$ Conversely, contacts who did not apply protective measures (e.g., face mask, avoiding contact with index case) had higher odds of infection. ${ }^{26}$ One study reported that greater frequency of chlorine or ethanol based disinfectant use for house cleaning and ventilation hours per day were associated with reduced risk, ${ }^{28}$ whereas another did not. ${ }^{26}$ Frequency of room cleaning (wet type) and hand hygiene were not significant. ${ }^{28}$ Index case isolation after illness onset was associated with reduced secondary transmission. ${ }^{31}$ Other studies did not find the time interval from illness onset to medical isolation, ${ }^{28}$ hospital admission, ${ }^{14,26,28}$ or laboratory confirmation, ${ }^{14,28}$ to be associated with transmission. Self-awareness of being infected with SARS-CoV-2 and knowledge of COVID-19 were not significant, ${ }^{28}$ but lack of knowledge of index case's own infectiousness was associated with transmission. ${ }^{28}$ Health profession of the index case was a protective factor in one study. ${ }^{43}$

\section{Household characteristics}

Smaller households were associated with transmission in two, ${ }^{22,43}$ of six studies..$^{26,28,41,42}$ Figure 9 summarizes the results from four studies reporting household SAR by number of contacts in the household. The estimated mean household SAR for households with one contact $(45 \cdot 2 \%$; $95 \%$ CI:

$34 \cdot 1 \%-51 \cdot 8 \%)$ was significantly higher than households with $\geq$ three contacts $(25 \cdot 1 \%$; $95 \%$ CI: $11 \cdot 1 \%$ -

$39 \cdot 1 \%)(P<0 \cdot 001)$, but not significantly different than households with two contacts $(47 \cdot 0 \%$; 95\% CI:

16.8\%-77.1\%). There was significant heterogeneity in SAR between studies with two $(P<0 \cdot 001)$ or 
medRxiv preprint doi: https://doi.org/10.1101/2020.07.29.20164590; this version posted August 1, 2020. The copyright holder for this preprint (which was not certified by peer review) is the author/funder, who has granted medRxiv a license to display the preprint in perpetuity.

It is made available under a CC-BY-NC-ND 4.0 International license .

$\geq$ three contacts $(P<0 \cdot 001)$, and but not one contact. A limitation here is that we have no information about household crowding (e.g., number of people per room).

Figure 9. Secondary attack rates (SAR) by the number of contacts in the household.

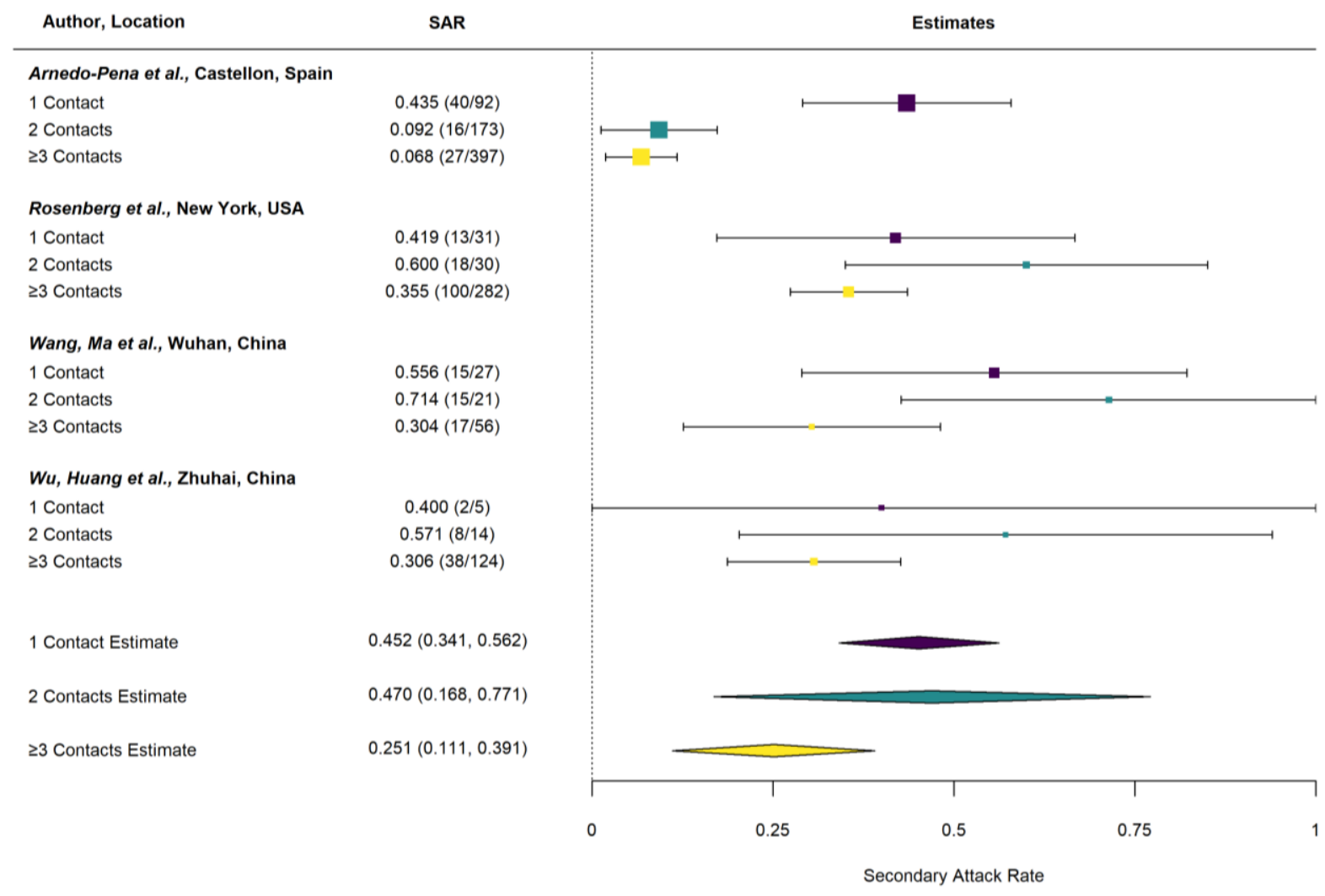

\section{Comparison with other viruses}

To compare SARS-CoV-2 SARs with other viruses, we reviewed articles describing household secondary transmission of SARS-CoV, Middle East Respiratory Syndrome coronavirus (MERS-CoV), and other coronaviruses. We found seven articles reporting household SARs of MERS-CoV, ${ }^{61-67}$ six of SARS-CoV, ${ }^{68-73}$ and four of other coronaviruses (S3 Table). ${ }^{74-77}$

The estimated mean household SAR was $6 \cdot 0 \%$ (95\% CI: $2 \cdot 2 \%-9 \cdot 8 \%)$ for SARS-CoV with no significant heterogeneity and 3.5\% (95\% CI: $0 \cdot 1 \%-6 \cdot 8 \%)$ for MERS-CoV with no significant heterogeneity (Figure 10), which were both lower than the overall household SAR of $18 \cdot 8 \%$ for SARSCoV-2 in this study $(P=0 \cdot 002)$. The SAR for SARS-CoV-2 was also higher than SARs reported for 
medRxiv preprint doi: https://doi.org/10.1101/2020.07.29.20164590; this version posted August 1, 2020. The copyright holder for this preprint (which was not certified by peer review) is the author/funder, who has granted medRxiv a license to display the preprint in perpetuity.

It is made available under a CC-BY-NC-ND 4.0 International license .

other coronaviruses: $0-12 \cdot 6 \%$ for $\mathrm{HCoV}-\mathrm{NL} 63,10 \cdot 6-13 \cdot 2 \%$ for $\mathrm{HCoV}-\mathrm{OC} 43,7 \cdot 2-14 \cdot 9 \%$ for $\mathrm{HCoV}$ 229E, $8 \cdot 6 \%$ for HCoV-HKU1, ${ }^{74,76,77}$ and $2 \cdot 6 \%$ for an unspecified novel coronavirus. ${ }^{75}$ Household SARs for SARS-CoV-2 appear to be within the upper ranges of household SARs reported for influenza, which ranged from 1-38\% based on PCR-confirmed infection, 6-35\% based on influenza-like illness, and 3$31 \%$ based on acute respiratory illness. ${ }^{13}$

Figure 10. Household secondary attack rates (SAR) for severe acute respiratory syndrome coronavirus (SARS-CoV) and Middle East Respiratory Syndrome coronavirus (MERS-CoV).

Author, Location
SARS-CoV
Chan et al., Hong Kong, China
Wilson-Clark et al., Toronto, Canada
Lau et al., Hong Kong, China
Goh et al., Singapore
Ou et al., Beijing, China
Lee et al., Taiwan
Subgroup Estimate
MERS-CoV
Arwady et al., Al-Qouz, Saudi Arabia
Payne et al., Jordan
Van Kerkhove et al., Riyadh, Saudi Arabia
Drosten et al., Saudi Arabia
Assiri et al., Al-Hasa, Saudi Arabia
Memish et al., Al-Madinah al-Munawwarah, Saudi Arabia
Al Hosani et al., Abu Dhabi, United Arab Emirates
Subgroup Estimate

\section{Discussion}

We synthesize available evidence on household studies of SARS-CoV-2. Combined household and family SAR is approximately $19 \%$, which is higher than previously observed SARs for SARS-CoV and MERS-CoV. Results suggest that household and family contacts are at higher risk than other types of contacts. We observed that household SARs were higher from symptomatic index cases than asymptomatic index cases, to adult contacts than children contacts, to spouses than other family contacts, and in households with one contact than households with three or more contacts. We also found some 
limited evidence of overdispersion in the number of infections caused by index cases, highlighting potential heterogeneity in transmissibility of index cases.

The household may be a favorable environment for transmission due to the frequency of contacts between family members, reduced usage of personal protective equipment, shared living and eating environment, persistence of SARS-CoV-2 on different surfaces, ${ }^{78}$ and potential fecal shedding in shared toilets. ${ }^{79}$ Modeling studies demonstrated that household transmission had a greater impact on $R$ after social distancing (30\%-55\%) compared to before social distancing (5\%-35\%). ${ }^{80}$

We found significantly higher SARs from symptomatic index cases than asymptomatic index cases, but many studies acknowledged potential underreporting of asymptomatic cases. There were also relatively few studies with separately reported asymptomatic index cases. Prolonged unprotected exposure to symptomatic case patients increases risk of transmission through respiratory droplets, by direct contact, or contact with fomites. ${ }^{11}$ Modeling studies have suggested, however, that asymptomatic index cases may also be important drivers of SARS-CoV-2 transmission, particularly from presymptomatic cases. ${ }^{81-84}$

SARs were higher to adult contacts than children contacts. Lower infection rates in children may in part be attributed to asymptomatic or mild disease and low case ascertainment. ${ }^{85}$ Few household studies reported SARs by index case age, but data suggests children have not played a substantive role in household transmission of SARS-CoV-2. ${ }^{86-88}$ A large study in South Korea that included 10,592 household contacts, however, noted relatively high transmission from index cases who were 10-19 years of age contracted COVID-19. ${ }^{33}$ Although children seem to be at reduced risk for symptomatic disease, it is still unclear whether they shed virus similar to adults. ${ }^{89}$

The finding that households with only one contact had higher SARs than households with greater than two contacts may suggest that household crowding and residential area per person are more important for SARS-CoV-2 transmission than the total number of people per household. Household crowding (e.g., the number of people per room) was demonstrated to be associated with influenza transmission. ${ }^{90-92}$ 
medRxiv preprint doi: https://doi.org/10.1101/2020.07.29.20164590; this version posted August 1, 2020. The copyright holder for this preprint (which was not certified by peer review) is the author/funder, who has granted medRxiv a license to display the preprint in perpetuity.

It is made available under a CC-BY-NC-ND 4.0 International license .

The observation that spouse relationship to the index case was a significant risk factor for secondary transmission is consistent with studies of SARS-CoV and H1N1. ${ }^{93,94}$ This may be a reflection of intimacy, sleeping in the same room, or longer or more direct exposure to index cases. One study detected SARS-CoV-2 in semen. ${ }^{95}$ Further investigation is required to determine whether sexual contact is a transmission route.

We did not find associations between household contact or index case sex and secondary transmission. WHO reports roughly even distribution of SARS-CoV-2 infections between women and men worldwide with higher mortality in men, ${ }^{96}$ perhaps due to delayed viral clearance of SARS-CoV-2, ${ }^{97}$ but acknowledges limited availability of sex-aggregated data. One study of mice showed that female mice were less susceptible to SARS-CoV than male mice, due in part to protection from estrogen receptor signaling and activity of X-linked genes. ${ }^{98}$

Household SARs were higher for SARS-CoV-2 than SARS-CoV and MERS-CoV, which may be attributed to structural differences in spike proteins, ${ }^{99}$ higher basic reproductive rates, ${ }^{100}$ and higher viral loads in the nose and throat at the time of symptom onset. ${ }^{101}$ Severe symptoms associated with MERS and SARS often require hospitalization, which increases nosocomial transmission, whereas less severe symptoms of SARS-CoV-2 facilitate community transmission. ${ }^{101}$

Although the pandemic transcends languages and culture, standardization of reporting procedures would facilitate comparisons of published studies. To expedite comparison of studies, it would be helpful for investigators to report the number of infected contacts and total contacts by specific characteristics of contacts (e.g., age group, sex, relationship, others) and by characteristics of index cases (e.g., symptomatic/asymptomatic, age group, others). To better understand clustering within households, it would also be useful for researchers to report the number of infections by household in addition to the total number of infected individuals.

Our study had several limitations. The large amount of unexplained heterogeneity across studies could be attributable to variability in study definitions of index cases and household contacts, frequency and type of testing, sociodemographic factors, household characteristics (e.g., density, air ventilation), 
rates of community transmission, and local policies (e.g., centralized isolation). Many of the studies involved testing symptomatic household contacts, which likely missed asymptomatic infections, although SAR estimates were similar across studies testing all contacts and only symptomatic contacts.

Conversely, the estimates may overestimate household transmission from index cases to contacts because studies cannot typically rule out infection from outside the home (e.g., non-household contact, fomite).

Important questions remain about the household spread of SARS-CoV-2 including the efficiency of asymptomatic transmission, probability of fecal-oral transmission, role of children in potential of reinfection, and sexual transmission of SARS-CoV-2. ${ }^{102}$ To prevent the spread of SARS-CoV-2, people are being asked to stay at home worldwide. With suspected cases frequently referred to isolate at home, household transmission will continue to be a significant source of transmission. Prevention strategies such as increased mask-wearing in the home, improved ventilation, voluntary isolation at external facilities, and targeted antiviral prophylaxis should be explored.

\section{Declaration of interests}

We declare no competing interests.

\section{Acknowledgments}

This work was supported by the National Institutes of Health R01-AI139761. 
medRxiv preprint doi: https://doi.org/10.1101/2020.07.29.20164590; this version posted August 1, 2020. The copyright holder for this preprint (which was not certified by peer review) is the author/funder, who has granted medRxiv a license to display the preprint in perpetuity.

It is made available under a CC-BY-NC-ND 4.0 International license .

\section{References}

1. Centers for Disease Control and Prevention. Coronavirus Disease 2019 (COVID-19): World Map. 2020. https://www.cdc.gov/coronavirus/2019-ncov/global-covid-19/world-map.html.

2. Wu Z, McGoogan JM. Characteristics of and important lessons from the coronavirus disease 2019 (COVID-19) outbreak in China: summary of a report of 72314 cases from the Chinese Center for Disease Control and Prevention. JAMA 2020; 323(13): 1239-42.

3. CDC Covid Response Team. Severe outcomes among patients with coronavirus disease 2019 (COVID-19)-United States, February 12-March 16, 2020. MMWR Morb Mortal Wkly Rep 2020; 69(12): 343-6.

4. World Health Organization. Transmission of SARS-CoV-2: implications for infection prevention precautions. 2020. https://www.who.int/news-room/commentaries/detail/transmission-of-sarscov-2-implications-for-infection-prevention-precautions.

5. Oran DP, Topol EJ. Prevalence of Asymptomatic SARS-CoV-2 Infection: A Narrative Review. Annals of Internal Medicine 2020.

6. Nishiura H, Oshitani H, Kobayashi T, et al. Closed environments facilitate secondary transmission of coronavirus disease 2019 (COVID-19). medRxiv 2020.

7. Badr HS, Du H, Marshall M, Dong E, Squire MM, Gardner LM. Association between mobility patterns and COVID-19 transmission in the USA: a mathematical modelling study. The Lancet Infectious Diseases 2020.

8. Drake TM, Docherty AB, Weiser TG, Yule S, Sheikh A, Harrison EM. The effects of physical distancing on population mobility during the COVID-19 pandemic in the UK. The Lancet Digital Health 2020.

9. Fang H, Wang L, Yang Y. Human mobility restrictions and the spread of the novel coronavirus (2019-ncov) in china: National Bureau of Economic Research, 2020.

10. Gudbjartsson DF, Helgason A, Jonsson H, et al. Spread of SARS-CoV-2 in the Icelandic Population. New England Journal of Medicine 2020; 382(24): 2302-15.

11. World Health Organization. Report of the WHO-China Joint Mission on Coronavirus Disease 2019 (COVID-19) 2020. https://www.who.int/docs/default-source/coronaviruse/who-china-jointmission-on-covid-19-final-report.pdf.

12. Centers for Disease Control and Prevention. Coronavirus Disease 2019 (COVID-19): How to Protect Yourself \& Others. 2020. https://www.cdc.gov/coronavirus/2019-ncov/prevent-gettingsick/prevention.html.

13. Tsang TK, Lau LLH, Cauchemez S, Cowling BJ. Household Transmission of Influenza Virus. Trends in Microbiology 2016; 24(2): 123-33.

14. Xin H, Jiang F, Xue A, et al. Risk factors associated with occurrence of COVID-19 among household persons exposed to patients with confirmed COVID-19 in Qingdao Municipal, China. Transboundary and Emerging Diseases 2020. 
medRxiv preprint doi: https://doi.org/10.1101/2020.07.29.20164590; this version posted August 1, 2020. The copyright holder for this preprint (which was not certified by peer review) is the author/funder, who has granted medRxiv a license to display the preprint in perpetuity.

It is made available under a CC-BY-NC-ND 4.0 International license .

15. Sun WW, Ling F, Pan JR, et al. [Epidemiological characteristics of 2019 novel coronavirus family clustering in Zhejiang Province]. Zhonghua Yu Fang Yi Xue Za Zhi 2020; 54(0): E027.

16. Yu HJ, Hu YF, Liu XX, et al. Household infection: The predominant risk factor for close contacts of patients with COVID-19. Travel Medicine and Infectious Disease 2020; 36: 101809.

17. Luo L, Liu D, Liao X-1, et al. Modes of Contact and Risk of Transmission in COVID-19: A Prospective Cohort Study 4950 Close Contact Persons in Guangzhou of China. 2020.

18. Bi Q, Wu Y, Mei S, et al. Epidemiology and transmission of COVID-19 in 391 cases and 1286 of their close contacts in Shenzhen, China: a retrospective cohort study. The Lancet Infectious Diseases 2020.

19. Chen Y, Wang AH, Yi B, et al. [Epidemiological characteristics of infection in COVID-19 close contacts in Ningbo city]. Zhonghua Liu Xing Bing Xue Za Zhi 2020; 41(5): 667-71.

20. Dong XC, Li JM, Bai JY, et al. [Epidemiological characteristics of confirmed COVID-19 cases in Tianjin]. Zhonghua Liu Xing Bing Xue Za Zhi 2020; 41(5): 638-41.

21. Hua CZ, Miao ZP, Zheng JS, et al. Epidemiological features and viral shedding in children with SARS-CoV-2 infection. Journal of Medical Virology 2020.

22. Jing Q-L, Liu M-J, Yuan J, et al. Household secondary attack rate of COVID-19 and associated determinants in Guangzhou, China: a retrospective cohort study. The Lancet Infectious Diseases 2020 .

23. Zhang JZ, Zhou P, Han DB, et al. [Investigation on a cluster epidemic of COVID-19 in a supermarket in Liaocheng, Shandong province]. Zhonghua Liu Xing Bing Xue Za Zhi 2020; 41(0): E055.

24. Wu Y, Song S, Kao Q, Kong Q, Sun Z, Wang B. Risk of SARS-CoV-2 infection among contacts of individuals with COVID-19 in Hangzhou, China. Public Health 2020; 185: 57-9.

25. Zhang W, Cheng W, Luo L, et al. Secondary Transmission of Coronavirus Disease from Presymptomatic Persons, China. Emerging Infectious Diseases 2020; 26(8).

26. Wu J, Huang Y, Tu C, et al. Household Transmission of SARS-CoV-2, Zhuhai, China, 2020. Clinical Infectious Diseases 2020.

27. Wang X, Zhou Q, He Y, et al. Nosocomial outbreak of COVID-19 pneumonia in Wuhan, China. The European Respiratory Journal 2020; 55(6).

28. Wang Y, Tian H, Zhang L, et al. Reduction of secondary transmission of SARS-CoV-2 in households by face mask use, disinfection and social distancing: a cohort study in Beijing, China. BMJ Global Health 2020; 5(5): e002794.

29. Wang Z, Ma W, Zheng X, Wu G, Zhang R. Household transmission of SARS-CoV-2. The Journal of Infection 2020.

30. Liu T, Liang W, Zhong H, et al. Risk factors associated with COVID-19 infection: a retrospective cohort study based on contacts tracing. Emerging Microbes \& Infections 2020: 1-31.

31. Li W, Zhang B, Lu J, et al. The characteristics of household transmission of COVID-19. Clinical Infectious Diseases 2020. 
medRxiv preprint doi: https://doi.org/10.1101/2020.07.29.20164590; this version posted August 1, 2020. The copyright holder for this preprint (which was not certified by peer review) is the author/funder, who has granted medRxiv a license to display the preprint in perpetuity.

It is made available under a CC-BY-NC-ND 4.0 International license .

32. Wang X, Pan Y, Zhang D, et al. Basic epidemiological parameter values from data of real-world in mega-cities: the characteristics of COVID-19 in Beijing, China. BMC Infectious Diseases 2020; $20(1): 526$.

33. Park YJ, Choe YJ, Park O, et al. Contact Tracing during Coronavirus Disease Outbreak, South Korea, 2020.

34. Coronavirus Disease-19: Summary of 2,370 Contact Investigations of the First 30 Cases in the Republic of Korea. Osong Public Health and Research Perspectives 2020; 11(2): 81-4.

35. Lee M, Eun Y, Park K, Heo J, Son H. Follow up investigation of asymptomatic COVID-19 cases at diagnosis in Busan, Korea. Epidemiology and Health 2020; 0(0): e2020046-0.

36. Son $\mathrm{H}$, Lee H, Lee M, et al. Epidemiological characteristics of and containment measures for coronavirus disease 2019 in Busan Metropolitan City, South Korea. Epidemiology and Health 2020: e2020035.

37. Park SY, Kim Y-M, Yi S, et al. Coronavirus Disease Outbreak in Call Center, South Korea. Emerging Infectious Diseases 2020; 26(8).

38. Yousaf AR, Duca LM, Chu V, et al. A prospective cohort study in non-hospitalized household contacts with SARS-CoV-2 infection: symptom profiles and symptom change over time. Clinical Infectious Diseases 2020.

39. Burke RM. Active monitoring of persons exposed to patients with confirmed COVID-19-United States, January-February 2020. MMWR Morbidity and mortality weekly report 2020; 69.

40. Dawson P, Rabold EM, Laws RL, et al. Loss of Taste and Smell as Distinguishing Symptoms of COVID-19. Clinical Infectious Diseases 2020.

41. Rosenberg ES, Dufort EM, Blog DS, et al. COVID-19 Testing, Epidemic Features, Hospital Outcomes, and Household Prevalence, New York State-March 2020. Clinical Infectious Diseases 2020.

42. Pollán M, Pérez-Gómez B, Pastor-Barriuso R, et al. Prevalence of SARS-CoV-2 in Spain (ENECOVID): a nationwide, population-based seroepidemiological study. Lancet 2020.

43. Arnedo-Pena A, Sabater-Vidal S, Meseguer-Ferrer N, et al. COVID-19 secondary attack rate and risk factors in household contacts in Castellon (Spain): Preliminary report. Enfermedades Emergentes 2020; 19(2): 64-70.

44. Draper AD, Dempsey KE, Boyd RH, et al. The first 2 months of COVID-19 contact tracing in the Northern Territory of Australia, March-April 2020. Communicable Diseases Intelligence 2020; 44.

45. Silveira M, Barros A, Horta B, et al. Repeated population-based surveys of antibodies against SARS-CoV-2 in Southern Brazil. medRxiv 2020.

46. Chaw L, Koh WC, Jamaludin SA, Naing L, Alikhan MF, Wong J. SARS-CoV-2 transmission in different settings: Analysis of cases and close contacts from the Tablighi cluster in Brunei Darussalam. medRxiv 2020. 
medRxiv preprint doi: https://doi.org/10.1101/2020.07.29.20164590; this version posted August 1, 2020. The copyright holder for this preprint (which was not certified by peer review) is the author/funder, who has granted medRxiv a license to display the preprint in perpetuity.

It is made available under a CC-BY-NC-ND 4.0 International license .

47. Böhmer MM, Buchholz U, Corman VM, et al. Investigation of a COVID-19 outbreak in Germany resulting from a single travel-associated primary case: a case series. The Lancet Infectious Diseases 2020.

48. Laxminarayan R, Wahl B, Dudala SR, et al. Epidemiology and transmission dynamics of COVID-19 in two Indian states. medRxiv 2020.

49. Dattner I, Goldberg Y, Katriel G, et al. The role of children in the spread of COVID-19: Using household data from Bnei Brak, Israel, to estimate the relative susceptibility and infectivity of children. medRxiv 2020.

50. Boscolo-Rizzo P, Borsetto D, Spinato G, et al. New onset of loss of smell or taste in household contacts of home-isolated SARS-CoV-2-positive subjects. European Archives of Oto-rhinolaryngology 2020: 1-4.

51. Yung CF, Kam KQ, Chong CY, et al. Household Transmission of SARS-CoV-2 from Adults to Children. The Journal of Pediatrics 2020.

52. Cheng HY, Jian SW, Liu DP, Ng TC, Huang WT, Lin HH. Contact Tracing Assessment of COVID-19 Transmission Dynamics in Taiwan and Risk at Different Exposure Periods Before and After Symptom Onset. JAMA Internal Medicine 2020.

53. Patel A, Charani E, Ariyanayagam D, et al. New-onset anosmia and ageusia in adult patients diagnosed with SARS-CoV-2 infection. Clinical Microbiology and Infection 2020.

54. R Core Team. R: A language and environment for statistical computing. Vienna, Austria; 2013.

55. Viechtbauer W. Conducting meta-analyses in $\mathrm{R}$ with the metafor package. Journal of statistical software 2010; 36(3): 1-48.

56. Stringhini S, Wisniak A, Piumatti G, et al. Seroprevalence of anti-SARS-CoV-2 IgG antibodies in Geneva, Switzerland (SEROCoV-POP): a population-based study. Lancet 2020.

57. Yang K, Wang L, Li F, et al. Analysis of epidemiological characteristics of coronavirus 2019 infection and preventive measures in Shenzhen China: a heavy population city. medRxiv 2020: 2020.02.28.20028555.

58. Fontanet A, Grant R, Tondeur L, et al. SARS-CoV-2 infection in primary schools in northern France: A retrospective cohort study in an area of high transmission. medRxiv 2020: 2020.06.25.20140178.

59. $\mathrm{Xu} \mathrm{X}$, Sun J, Nie S, et al. Seroprevalence of immunoglobulin M and G antibodies against SARSCoV-2 in China. Nature Medicine 2020: 1-3.

60. Fontanet A, Tondeur L, Madec Y, et al. Cluster of COVID-19 in northern France: A retrospective closed cohort study. medRxiv 2020: 2020.04.18.20071134.

61. Al Hosani FI, Kim L, Khudhair A, et al. Serologic Follow-up of Middle East Respiratory Syndrome Coronavirus Cases and Contacts-Abu Dhabi, United Arab Emirates. Clinical Infectious Diseases 2019; 68(3): 409-18. 
medRxiv preprint doi: https://doi.org/10.1101/2020.07.29.20164590; this version posted August 1, 2020. The copyright holder for this preprint (which was not certified by peer review) is the author/funder, who has granted medRxiv a license to display the preprint in perpetuity.

It is made available under a CC-BY-NC-ND 4.0 International license .

62. Arwady MA, Alraddadi B, Basler C, et al. Middle East respiratory syndrome coronavirus transmission in extended family, Saudi Arabia, 2014. Emerging Infectious Diseases 2016; 22(8): 1395.

63. Assiri A, McGeer A, Perl TM, et al. Hospital outbreak of Middle East respiratory syndrome coronavirus. The New England Journal of Medicine 2013; 369(5): 407-16.

64. Drosten C, Meyer B, Müller MA, et al. Transmission of MERS-coronavirus in household contacts. New England Journal of Medicine 2014; 371(9): 828-35.

65. Memish ZA, Al-Tawfiq JA, Alhakeem RF, et al. Middle East respiratory syndrome coronavirus (MERS-CoV): A cluster analysis with implications for global management of suspected cases. Travel Medicine and Infectious Disease 2015; 13(4): 311-4.

66. Payne DC, Biggs HM, Al-Abdallat MM, et al. Multihospital Outbreak of a Middle East Respiratory Syndrome Coronavirus Deletion Variant, Jordan: A Molecular, Serologic, and Epidemiologic Investigation. Open Forum Infectious Diseases 2018; 5(5): ofy095.

67. Van Kerkhove MD, Alaswad S, Assiri A, et al. Transmissibility of MERS-CoV infection in closed setting, Riyadh, Saudi Arabia, 2015. Emerging Infectious Diseases 2019; 25(10): 1802.

68. Chan LY, Wong JT, Li PK, Lui SF, Fung H, Sung J. Risk of transmission of severe acute respiratory syndrome to household contacts by infected health care workers and patients. The American Journal of Medicine 2004; 116(8): 559-60.

69. Goh DL, Lee BW, Chia KS, et al. Secondary household transmission of SARS, Singapore. Emerg Infect Dis 2004; 10(2): 232-4.

70. Lau JT, Lau M, Kim JH, Tsui HY, Tsang T, Wong TW. Probable secondary infections in households of SARS patients in Hong Kong. Emerg Infect Dis 2004; 10(2): 235-43.

71. Lee CC, Chen SY, Chang IJ, et al. Seroprevalence of SARS coronavirus antibody in household contacts. Epidemiology and Infection 2005; 133(6): 1119-22.

72. Wilson-Clark SD, Deeks SL, Gournis E, et al. Household transmission of SARS, 2003. Canadian Medical Association Journal 2006; 175(10): 1219-23.

73. Ou J, Li Q, Zeng G, Dun Z. Efficiency of quarantine during an epidemic of severe acute respiratory syndrome-Beijing, China, 2003. MMWR: Morbidity \& Mortality Weekly Report 2003; 52(43): 1037-.

74. Esposito S, Bosis S, Niesters HG, et al. Impact of human coronavirus infections in otherwise healthy children who attended an emergency department. Journal of Medical Virology 2006; 78(12): 1609-15.

75. Health Protection Agency UK Novel Coronavirus Investigation team. Evidence of person-toperson transmission within a family cluster of novel coronavirus infections, United Kingdom, February 2013. Euro surveillance: bulletin Européen sur les maladies transmissibles = European communicable disease bulletin 2013; 18(11): 20427.

76. Monto AS, DeJonge P, Callear AP, et al. Coronavirus occurrence and transmission over 8 years in the HIVE cohort of households in Michigan. The Journal of Infectious Diseases 2020. 
medRxiv preprint doi: https://doi.org/10.1101/2020.07.29.20164590; this version posted August 1, 2020. The copyright holder for this preprint (which was not certified by peer review) is the author/funder, who has granted medRxiv a license to display the preprint in perpetuity.

It is made available under a CC-BY-NC-ND 4.0 International license .

77. Beale S, Lewer D, Aldridge RW, et al. Household transmission of seasonal coronavirus infections: Results from the Flu Watch cohort study. Wellcome Open Research 2020; 5(145): 145.

78. Kampf G, Todt D, Pfaender S, Steinmann E. Persistence of coronaviruses on inanimate surfaces and their inactivation with biocidal agents. Journal of Hospital Infection 2020; 104(3): 246-51.

79. Parasa S, Desai M, Chandrasekar VT, et al. Prevalence of Gastrointestinal Symptoms and Fecal Viral Shedding in Patients With Coronavirus Disease 2019: A Systematic Review and Metaanalysis. JAMA Network Open 2020; 3(6): e2011335-e.

80. Curmei M, Ilyas A, Evans O, Steinhardt J. Estimating Household Transmission of SARS-CoV-2. medRxiv 2020.

81. Ferretti L, Wymant C, Kendall M, et al. Quantifying SARS-CoV-2 transmission suggests epidemic control with digital contact tracing. Science 2020; 368(6491): eabb6936.

82. Li R, Pei S, Chen B, et al. Substantial undocumented infection facilitates the rapid dissemination of novel coronavirus (SARS-CoV-2). Science 2020; 368(6490): 489-93.

83. Aguilar JB, Faust JS, Westafer LM, Gutierrez JB. Investigating the Impact of Asymptomatic Carriers on COVID-19 Transmission. medRxiv 2020: 2020.03.18.20037994.

84. Liu Y, Funk S, Flasche S. The contribution of pre-symptomatic infection to the transmission dynamics of COVID-2019. Wellcome Open Research 2020; 5(58): 58.

85. Mehta NS, Mytton OT, Mullins EWS, et al. SARS-CoV-2 (COVID-19): What do we know about children? A systematic review. Clinical Infectious Diseases 2020.

86. Posfay Barbe C, Wagner N, Gauthey M, et al. COVID-19 in Children and the Dynamics of Infection in Families. Pediatrics 2020: e20201576.

87. Lee B, Raszka WV. COVID-19 transmission and children: the child is not to blame. Pediatrics 2020 .

88. Zhu Y, Bloxham CJ, Hulme KD, et al. Children are unlikely to have been the primary source of household SARS-CoV-2 infections. medRxiv 2020: 2020.03.26.20044826.

89. L'Huillier AG, Torriani G, Pigny F, Kaiser L, Eckerle I. Shedding of infectious SARS-CoV-2 in symptomatic neonates, children and adolescents. medRxiv 2020: 2020.04.27.20076778.

90. Tam K, Yousey-Hindes K, Hadler JL. Influenza-related hospitalization of adults associated with low census tract socioeconomic status and female sex in $\mathrm{N}$ ew H aven $\mathrm{C}$ ounty, C onnecticut, 2007-2011. Influenza and Other Respiratory Viruses 2014; 8(3): 274-81.

91. Chandrasekhar R, Sloan C, Mitchel E, et al. Social determinants of influenza hospitalization in the United States. Influenza and Other Respiratory Viruses 2017; 11(6): 479-88.

92. Sloan C, Chandrasekhar R, Mitchel E, Schaffner W, Lindegren ML. Socioeconomic disparities and influenza hospitalizations, Tennessee, USA. Emerging infectious diseases 2015; 21(9): 1602.

93. Pang X, Zhu Z, Xu F, et al. Evaluation of control measures implemented in the severe acute respiratory syndrome outbreak in Beijing, 2003. Jama 2003; 290(24): 3215-21. 
medRxiv preprint doi: https://doi.org/10.1101/2020.07.29.20164590; this version posted August 1, 2020. The copyright holder for this preprint (which was not certified by peer review) is the author/funder, who has granted medRxiv a license to display the preprint in perpetuity.

It is made available under a CC-BY-NC-ND 4.0 International license .

94. Pang X, Yang P, Li S, et al. Pandemic (H1N1) 2009 among quarantined close contacts, Beijing, People's Republic of China. Emerging infectious diseases 2011; 17(10): 1824.

95. Li D, Jin M, Bao P, Zhao W, Zhang S. Clinical characteristics and results of semen tests among men with coronavirus disease 2019. JAMA network open 2020; 3(5): e208292-e.

96. World Health Organization. Gender and COVID-19. 2020.

https://www.who.int/publications/i/item/gender-and-covid-19.

97. Shastri A, Wheat J, Agrawal S, et al. Delayed clearance of SARS-CoV2 in male compared to female patients: High ACE2 expression in testes suggests possible existence of gender-specific viral reservoirs. medRxiv 2020: 2020.04.16.20060566.

98. Channappanavar R, Fett C, Mack M, Ten Eyck PP, Meyerholz DK, Perlman S. Sex-Based Differences in Susceptibility to Severe Acute Respiratory Syndrome Coronavirus Infection. Journal of immunology (Baltimore, Md : 1950) 2017; 198(10): 4046-53.

99. Rabaan AA, Al-Ahmed SH, Haque S, et al. SARS-CoV-2, SARS-CoV, and MERS-COV: A comparative overview. Le Infezioni in Medicina 2020; 28(2): 174-84.

100. Petersen E, Koopmans M, Go U, et al. Comparing SARS-CoV-2 with SARS-CoV and influenza pandemics. The Lancet Infectious Diseases 2020.

101. Petrosillo N, Viceconte G, Ergonul O, Ippolito G, Petersen E. COVID-19, SARS and MERS: are they closely related? Clinical Microbiology and Infection 2020.

102. Patrì A, Gallo L, Guarino M, Fabbrocini G. Sexual transmission of severe acute respiratory syndrome coronavirus 2 (SARS-CoV-2): A new possible route of infection? Journal of the American Academy of Dermatology 2020. 